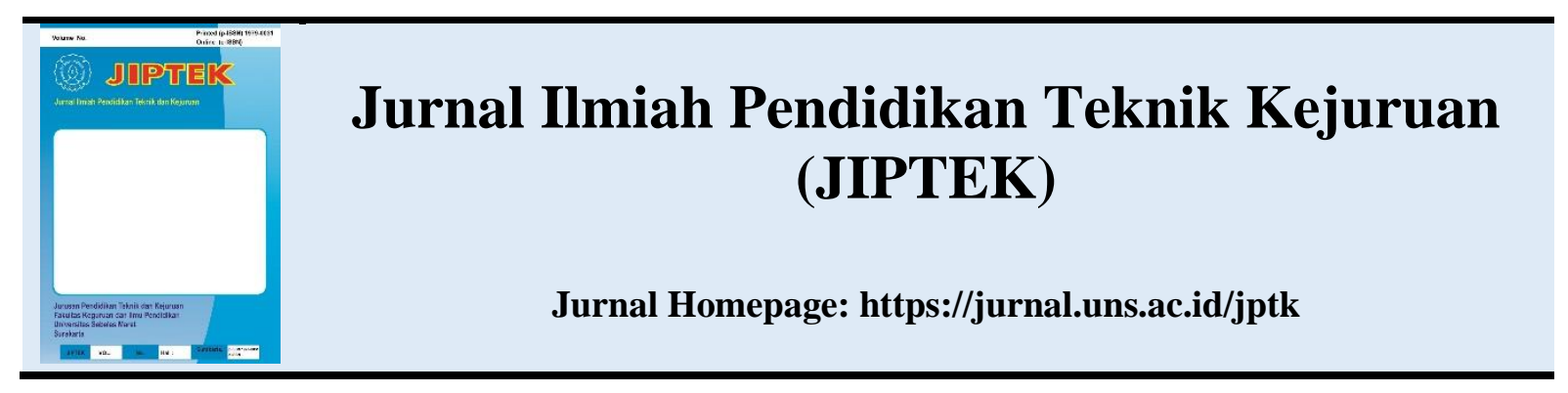

\title{
PENGARUH PENAMBAHAN SERAT LIMBAH BANNER TERHADAP KUAT LEKAT DAN MIKROSTRUKTUR BETON SERAT PASCA BAKAR SEBAGAI SUPLEMEN BAHAN AJAR MATA KULIAH TEKNOLOGI BETON
}

\author{
Anis Rahmawati ${ }^{1}$, Roemintoyo ${ }^{2}$, Aryanti Nurhidayati ${ }^{3}$, Ida Nugroho Saputro, Langgeng Setyo \\ Pramono $^{4}$ \\ 1,2,3,4 Program Studi Pendidikan Teknik Bangunan, Universitas Sebelas Maret \\ E-mail: anisrahmawati79@gmail.com
}

\begin{abstract}
ABSTRAK
Tujuan dari penelitian ini antara lain, 1) mengetahui pengaruh penambahan serat limbah banner dengan variasi panjang serat dan variasi suhu pembakaran terhadap kuat lekat beton pasca bakar, 2) mengetahui perubahan mikrostruktur beton dengan penambahan serat limbah banner pada beberapa variasi panjang serat dan variasi suhu pembakaran pra dan pasca bakar, 3) mengetahui nilai optimum penambahan serat limbah banner yang akan menghasilkan beton dengan kuat lekat maksimal beton pasca bakar. Hasil penelitian sebagai berikut 1) penambahan panjang serat limbah banner mengakibatkan penurunan pada suhu $300^{\circ} \mathrm{C}$ dan kenaikan pada suhu $400^{\circ} \mathrm{C}$, 2) perubahan mikrostruktur beton dengan penambahan serat limbah banner pada beberapa variasi panjang serat dan variasi suhu pembakaran dapat dilihat dari pori- pori dan retakan mikro pada beton pasca bakar yang terlihat lebih banyak daripada beton pra bakar, 3) penambahan panjang serat limbah banner yang menghasilkan nilai maksimal kuat lekat beton pasca bakar terjadi pada penambahan panjang serat limbah banner $3 \mathrm{~cm}$ dengan suhu pembakaran $200^{\circ} \mathrm{C}$.
\end{abstract}

Kata Kunci : beton serat, kuat lekat, mikrostruktur, pasca bakar, serat banner

\begin{abstract}
The purpose of this study, 1) know how the addition of fiber length variation of banners and combustion temperature variations to bond strength post-burn concrete, 2) know the change of microstructures of concrete by the addition of fiber the waste banner on some variations of the length of the fiber and temperature variations pre and post-burn, 3) know optimum value the addition of fiber waste banner that will produce concrete with bond strength post-burn concrete maximum.This research using quantitative research methods with experimental approach. Variables that affect in this study is 1) free variables include the addition of long fiber waste banner that is $3 \mathrm{~cm}, 6 \mathrm{~cm}, 9 \mathrm{~cm}$ and in the amount of $0.2 \%$ of the weight of the concrete and the temperature variation of combustion that is room temperature $\left(28{ }^{\circ} \mathrm{C}\right), 200^{\circ} \mathrm{C}{ }^{\circ} \mathrm{C}, 300$, and $400{ }^{\circ} \mathrm{C}$, 2) variable bound to include bond strength and microstructures of concrete due to variations in the length of the fiber waste banner and combustion temperature variations. Research results as follows 1) addition of long fiber waste banner resulting in a decrease in the temperature of $300{ }^{\circ} \mathrm{C}$ and rise at a temperature of $\left.400{ }^{\circ} \mathrm{C}, 2\right)$ change in microstructures of concrete with addition of waste fiber banner on some variations of the length of the fiber and combustion temperature variations can be seen from the pores and cracks in the concrete post-burn that looks more than concrete pre-burn, 3) addition of long fiber waste banner that generates maximum value bond strength the concrete post-burn occurred at the addition of long fiber waste banner $3 \mathrm{~cm}$ with combustion temperatures $200^{\circ} \mathrm{C}$.
\end{abstract}

Keywords : bond strength, concrete fibers, fiber banners, microstructure, post-burn 


\section{PENDAHULUAN}

Peristiwa kebakaran bangunan gedung yang sering terjadi kebanyakan menggunakan struktur beton bertulang sebagai elemen konstruksinya. Beton pada dasarnya tidak diharapkan mampu menahan panas sampai suhu tinggi. Menurut Wahyuni, E. dan Anggraini, R. (2010) panas atau suhu sebagai beban pada struktur perlu dikaji mengingat daya rusaknya terhadap regangan, modulus elasitas, dan tegangan pada bahan struktur yang bersangkutan. Terjadinya perubahan temperatur yang cukup tinggi, seperti yang terjadi pada peristiwa kebakaran, akan membawa dampak pada struktur beton. Karena pada proses tersebut akan terjadi suatu siklus pemanasan dan pendinginan yang bergantian, yang akan menyebabkan adanya perubahan fase fisis dan kimiawi secara kompleks. Hal ini akan mempengaruhi kualitas/kekuatan struktur beton tersebut dan akan menyebabkan beton menjadi getas.

Akan tetapi dibandingkan dengan material lain, beton merupakan bahan bangunan yang memiliki daya tahan terhadap api yang relatif lebih baik, karena beton merupakan material yang memiliki daya hantar panas yang rendah, sehingga dapat menghalangi rambatan panas kebagian dalam struktur beton tersebut. Saat terbakar beton tidak dapat menghasilkan api namun dapat menyerap panas sehingga akan terjadi suhu tinggi yang berlebihan, yang akan mengakibatkan perubahan pada mikro struktur.

Pengaruh suhu tinggi pada beton juga mengakibatkan sifat daktilitas (getas) beton semakin rendah. Daktilitas beton yang rendah dicerminkan oleh kurva tegangan-regangannya yang memiliki penurunan kekuatan tekan yang cepat pada daerah beban pasca puncak, sehingga menyebabkan keruntuhan terjadi tibatiba. Penambahan serat yang mempunyai modulus elastisitas yang lebih rendah dari modulus elastisitas matrik beton diharapkan dapat membuat beton lebih daktail. Dengan sifat daktail tersebut, serat yang dicampurkan ke dalam beton diharapkan dapat digunakan untuk memperbaiki karakteristik beton (Adianto dan Basuki, 2004). Selain daktilitas beton juga memiliki kelemahan antara lain beton mempunyai sifat susut (shrinkage) dan kuat tarik yang sangat rendah yang ditandai dengan terjadinya retak pada bagian serat yang mengalami tarik sebelum akhirnya beton itu runtuh.

Salah satu cara untuk mengatasi daktilitas dan rendahnya kuat tarik beton yaitu dengan menambahkan bahan serat. Penggunaan serat untuk memperkuat material yang getas telah lama dikenal. Serat-serat yang telah umum dipergunakan antara lain terbuat dari baja, polymer, atau fiber glass. Salah satu jenis serat yang dapat dipakai adalah serat polymeric (Balaguru dan Shah, 1992). Pada penelitian ini mencoba memanfaatkan serat limbah banner. Serat dalam banner ini termasuk dalam jenis serat polypropelene. Banner adalah salah satu jenis media promosi yang sudah dicetak menggunakan print digital yang pada umumnya memiliki bentuk vertikal atau portrait. Banyak banner bekas yang sudah tidak terpakai atau digunakan oleh masyarakat luas. Dalam dunia konstruksi khususnya beton, banner ini dapat 
digunakan untuk bahan tambah dalam pembuatan beton.

Bahan pembuatan banner yang digunakan ini terbuat dari bahan vinyl/ sintesis semi plastik yang tidak mudah mengkusut dan tahan terhadap air. Didalam banner terdapat serat yang berbentuk seperti benang dapat digunakan untuk campuran beton. Serat bahan banner ini diharapkan dapat mengurangi retakretak karena susut akibat pembebanan sehingga akan meningkatkan kekuatan beton, salah satunya kuat lekat beton. Penelitian tentang pemanfaatan serat limbah banner sebagai campuran beton dapat menjadi alternatif baru dalam pembuatan beton.

Pada penelitian ini juga akan dilakukan perlakuan pembakaran terhadap beton. Karena sifat serat limbah banner yang mudah terbakar maka dengan dilakukannya pembakaran beton diharapkan bisa mengetahui apakah beton dapat melindungi serat limbah banner dari suhu tinggi serta sejauh mana daya tahan beton terhadap api. Seiring dengan tujuan yang ingin dicapai, penelitian ini dimaksudkan untuk mendapatkan gambaran tentang perubahan tingkat degradasi kekuatan lekat antara serat limbah banner dan beton bertulang bila diberi pemanasan dengan temperatur dan selama interval waktu tertentu. Dampak pemanasan terhadap kekuatan lekat antara serat limbah banner dan beton bertulang sangat tergantung pada perubahan mikrostruktur beton maupun material baja tulangan yang diakibatkan oleh reaksi fisik ataupun reaksi kimia serta pada akhirnya akan mempengaruhi kekuatan beton secara keseluruhan.

\section{METODE PENELITIAN}

Dalam penelitian ini menggunakan jenis penelitian kuantitatif. Menurut Sugiyono (2013 : 7) metode penelitian kuantitatif merupakan sebagai metode ilmiah/scientific karena telah memenuhi kaidah-kaidah ilmiah yaitu konkrit/empiris, obyektif, terukur, rasional dan sistematis. Metode ini disebut metode kuantitatif karena data penelitian berupa angkaangka dan analisis menggunakan statistik deskriptif dan analisis regresi. Penelitian kuantitatif yang dilakukan pada penelitian ini merupakan penelitian yang menggunakan pendekatan eksperimen. Menurut Sugiyono (2013 : 72) penelitian eksperimen dilakukan di laboratorium dan ada perlakuan (treatment), dengan demikian metode penelitian eksperimen dapat diartikan sebagai metode penelitian yang digunakan untuk mencari pengaruh perlakuan tertentu terhadap yang lain dalam kondisi yang terkendali. Dalam penelitian ini menggunakan benda uji berupa silinder dengan ukuran diameter $150 \mathrm{~mm}$ dan tinggi $300 \mathrm{~mm}$ dan pelat dengan ukuran $10 \mathrm{~mm}$ x $10 \mathrm{~mm}$ x $5 \mathrm{~mm}$ dibuat dengan menambahkan serat limbah banner. Setelah benda uji berumur 28 hari, benda uji dilakukan pembakaran. Setelah itu benda uji bisa dilakukan pengujian kuat lekat.

Dalam penelitian ini hanya akan dipakai 3 variabel yaitu sebagai berikut:

\section{Variabel Independen}

Variabel independen atau sering disebut variabel bebas adalah merupakan variabel yang mempengaruhi atau yang menjadi sebab perubahannya atau timbulnya variabel dependen (terikat) (Sugiyono (2013 : 39). 
Variabel bebas dari dalam penelitian ini adalah variasi panjang serat limbah banner dan suhu pembakaran beton.

\section{Variabel Dependen}

Variabel dependen atau yang sering disebut sebagai variabel terikat merupakan variabel yang dipengaruhi atau yang menjadi akibat, karena adanya variabel bebas (Sugiyono, 2013 : 39). Variabel terikat dalam penelitian ini adalah kuat lekat dan mikrostruktur beton.

\section{Variabel Kontrol}

Variabel kontrol adalah variabel yang dikendalikan atau dibuat konstan sehingga pengaruh variabel independen terhadap dependen tidak dipengaruhi oleh faktor luar yang tidak diteliti (Sugiyono, 2013 : 41). Variabel kontrol dalam penelitian ini adalah metode pencampuran bahan, metode perawatan, dan metode pengujian beton dibuat sama, beton yang dibuat dengan material yang sama, tempat penelitian sama dan peralatan untuk membuat maupun menguji benda uji sama.

\section{PEMBAHASAN}

Tabel 1. Hasil Uji Kuat Lekat Beton

\begin{tabular}{|c|c|c|c|c|c|c|c|}
\hline $\begin{array}{l}\text { Kode } \\
\text { Benda } \\
\text { Uji }\end{array}$ & $\begin{array}{l}\text { Panjang } \\
\text { Serat } \\
(\mathrm{cm})\end{array}$ & $\begin{array}{l}\text { Suhu } \\
\left({ }^{\circ} \mathbf{C}\right)\end{array}$ & $\begin{array}{l}\text { Diameter } \\
\text { Tulangan } \\
(\mathrm{cm})\end{array}$ & $\begin{array}{l}\text { Panjang } \\
\text { Penanaman } \\
\text { Tulangan }(\mathrm{cm})\end{array}$ & $\begin{array}{l}\text { Beban } \\
\text { Lekat } \\
(\text { kgf) }\end{array}$ & $\begin{array}{l}\text { Kuat } \\
\text { Lekat } \\
\text { (MPa) }\end{array}$ & $\begin{array}{l}\text { Kuat Lekat } \\
\text { Rata - Rata } \\
\text { (MPa) }\end{array}$ \\
\hline A2 & & & 1,05 & 15 & 1560 & 3,094 & \\
\hline A3 & 0 & 28 & 1,05 & 15 & 1820 & 3,610 & 3,233 \\
\hline A4 & & & 1,05 & 15 & 1510 & 2,995 & \\
\hline B2 & & & 1,05 & 15 & 1380 & 2,737 & \\
\hline B3 & & 200 & 1,05 & 15 & 1590 & 3,154 & 2,995 \\
\hline B4 & & & 1,05 & 15 & 1560 & 3,094 & \\
\hline $\mathrm{C} 1$ & & & 1,05 & 15 & 1640 & 3,253 & \\
\hline $\mathrm{C} 2$ & 0 & 300 & 1,05 & 15 & 1700 & 3,372 & 3,161 \\
\hline $\mathrm{C} 4$ & & & 1,05 & 15 & 1440 & 2,856 & \\
\hline D1 & & & 1,05 & 15 & 840 & 1,666 & \\
\hline $\mathrm{D} 2$ & & 400 & 1,05 & 15 & 1090 & 2,162 & 1,825 \\
\hline D3 & & & 1,05 & 15 & 830 & 1,646 & \\
\hline E2 & & & 1,05 & 15 & 1880 & 3,729 & \\
\hline E3 & 3 & 28 & 1,05 & 15 & 2100 & 4,166 & 3,709 \\
\hline E4 & & & 1,05 & 15 & 1630 & 3,233 & \\
\hline
\end{tabular}




\begin{tabular}{|c|c|c|c|c|c|c|c|}
\hline $\mathrm{F} 1$ & & & 1,05 & 15 & 1840 & 3,650 & \\
\hline $\mathrm{F} 2$ & & 200 & 1,05 & 15 & 1740 & 3,452 & 3,590 \\
\hline F3 & & & 1,05 & 15 & 1850 & 3,670 & \\
\hline G1 & & & 1,05 & 15 & 1120 & 2,222 & \\
\hline $\mathrm{G} 2$ & & 300 & 1,05 & 15 & 1140 & 2,261 & 2,460 \\
\hline G3 & & & 1,05 & 15 & 1460 & 2,896 & \\
\hline H1 & & & 1,05 & 15 & 1345 & 2,668 & \\
\hline $\mathrm{H} 2$ & & 400 & 1,05 & 15 & 920 & 1,825 & 2,159 \\
\hline H3 & & & 1,05 & 15 & 1000 & 1,984 & \\
\hline I1 & & & 1,05 & 15 & 1410 & 2,797 & \\
\hline I2 & & 28 & 1,05 & 15 & 1350 & 2,678 & 2,923 \\
\hline I4 & & & 1,05 & 15 & 1660 & 3,293 & \\
\hline $\mathrm{J} 2$ & & & 1,05 & 15 & 1600 & 3,174 & \\
\hline $\mathrm{J} 3$ & & 200 & 1,05 & 15 & 1880 & 3,729 & 3,293 \\
\hline $\mathrm{J} 4$ & & & 1,05 & 15 & 1500 & 2,975 & \\
\hline $\mathrm{K} 1$ & & & 1,05 & 15 & 1450 & 2,876 & \\
\hline $\mathrm{K} 2$ & & 300 & 1,05 & 15 & 1530 & 3,035 & 2,764 \\
\hline K3 & & & 1,05 & 15 & 1200 & 2,380 & \\
\hline L1 & & & 1,05 & 15 & 1360 & 2,698 & \\
\hline L3 & & 400 & 1,05 & 15 & 1400 & 2,777 & 2,532 \\
\hline $\mathrm{L} 4$ & & & 1,05 & 15 & 1070 & 2,122 & \\
\hline M1 & \multirow{12}{*}{9} & \multirow{3}{*}{28} & 1,05 & 15 & 1770 & 3,511 & \multirow{3}{*}{3,531} \\
\hline M2 & & & 1,05 & 15 & 1740 & 3,452 & \\
\hline M4 & & & 1,05 & 15 & 1830 & 3,630 & \\
\hline N1 & & & 1,05 & 15 & 1200 & 2,380 & \multirow{3}{*}{2,572} \\
\hline $\mathrm{N} 2$ & & 200 & 1,05 & 15 & 1340 & 2,658 & \\
\hline N3 & & & 1,05 & 15 & 1350 & 2,678 & \\
\hline $\mathrm{O} 1$ & & & 1,05 & 15 & 1370 & 2,718 & \multirow{3}{*}{2,777} \\
\hline $\mathrm{O} 3$ & & 300 & 1,05 & 15 & 1530 & 3,035 & \\
\hline $\mathrm{O} 4$ & & & 1,05 & 15 & 1300 & 2,579 & \\
\hline $\mathrm{P} 1$ & & & 1,05 & 15 & 1630 & 3,233 & \multirow{3}{*}{2,909} \\
\hline $\mathrm{P} 2$ & & 400 & 1,05 & 15 & 1370 & 2,718 & \\
\hline P3 & & & 1,05 & 15 & 1400 & 2,777 & \\
\hline
\end{tabular}




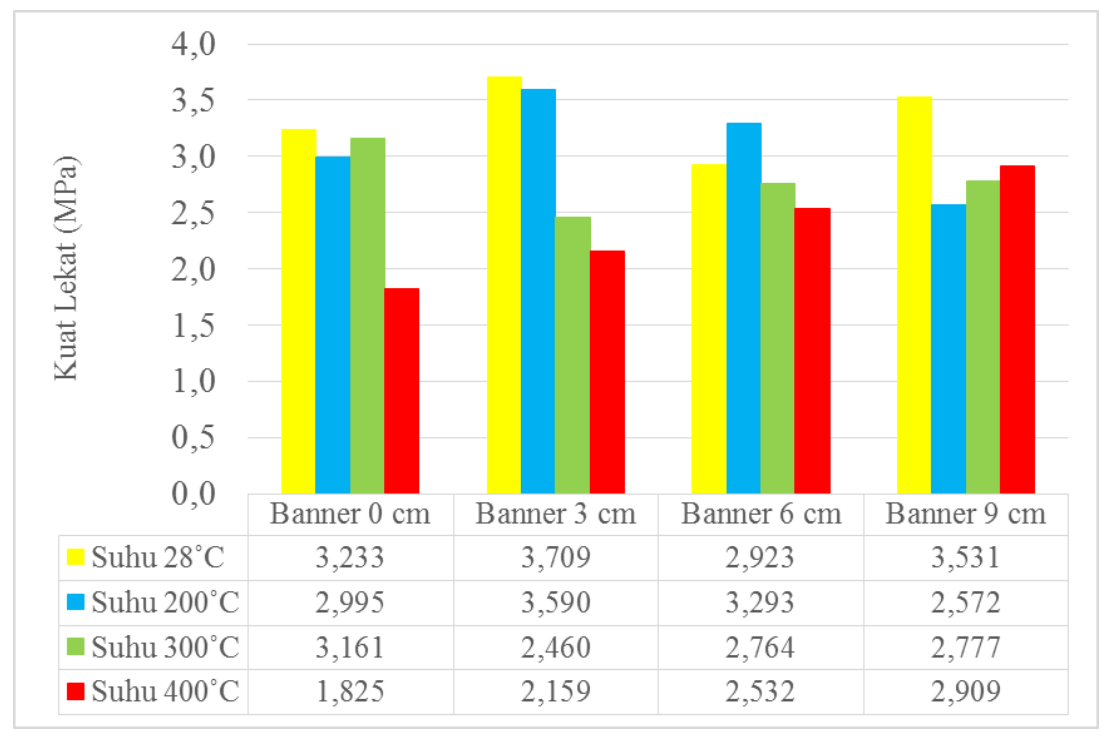

Gambar 1. Hasil Rekapitulasi Kuat Lekat Beton Serat Limbah Banner Pasca Bakar

Pengaruh penambahan serat limbah banner dengan variasi panjang serat terhadap kuat lekat beton pasca bakar

Berdasarkan perhitungan dari hasil uji kuat lekat dapat diketahui bahwa penambahan serat banner pada beton mempunyai pengaruh terhadap kuat lekat beton. Pengaruh tersebut cenderung meningkatkan kuat lekat beton. Dimana hanya pada suhu pembakaran $300^{\circ} \mathrm{C}$ kuat lekat beton mengalami penurunan pada semua variasi penambahan serat limbah banner sedangkan pada suhu pembakaran $400^{\circ} \mathrm{C}$ kuat lekat beton mengalami kenaikan pada semua variasi penambahan serat limbah banner. Sedangkan pada suhu pembakaran $200^{\circ} \mathrm{C}$ dan tanpa pembakaran kuat lekat beton mengalami fluktuatif. Penurunan kuat lekat tertinggi terjadi pada suhu pembakaran $300^{\circ} \mathrm{C}$ dengan variasi penambahan serat limbah banner $3 \mathrm{~cm}$ yaitu mengalami penurunan sebesar 22,176 \% . Sedangkan kenaikan kuat lekat tertinggi terjadi pada suhu pembakaran $400^{\circ} \mathrm{C}$ dengan variasi penambahan serat limbah banner $9 \mathrm{~cm}$ yaitu mengalami kenaikan sebesar $59,420 \%$. Sehingga berdasarkan hasil penelitian ini dapat disimpulkan bahwa dengan penambahan serat limbah banner dapat meningkatkan kuat lekat beton.

Edward G. Nawy (1990: 398) berpendapat bahwa kuat lekat beton dan baja tulangan tergantung pada faktor-faktor utama yaitu adanya adhesi antara elemen beton dan bahan penguatnya, efek memegang (griping) sebagai akibat dari susut pengeringan beton sekeliling tulangan dan saling geser antara tulangan beton dengan sekelilingnya, faktor diameter, bentuk dan jarak tulangan mempengaruhi retakan, tahan gesekan (friction) terhadap gelinciran dan saling mengait dengan tulangan mengalami gaya tarik.

Pengaruh penambahan serat limbah banner dengan variasi suhu pembakaran terhadap kuat lekat beton pasca bakar

Berdasarkan perhitungan dari hasil uji kuat lekat dapat diketahui bahwa suhu pembakaran beton mempunyai pengaruh 
terhadap kuat lekat beton. Dimana hampir disetiap suhu pembakaran kuat lekat beton mengalami penurunan, hanya pada variasi penambahan serat limbah banner $6 \mathrm{~cm}$ dengan suhu pembakaran $200^{\circ} \mathrm{C}$ kuat lekat beton mengalami kenaikan yaitu $12,67 \%$ dan penurunan kuat lekat tertinggi terjadi pada beton tanpa penambahan serat limbah banner dengan suhu pembakaran $400^{\circ} \mathrm{C}$ yaitu mengalami penurunan sebesar 43,558 \%.
Sehingga berdasarkan hasil tersebut dapat disimpulkan bahwa dengan pembakaran beton serat limbah banner dapat menurunkan kuat lekat beton.

Untuk mengetahui pengaruh dari variabel bebas (penambahan serat limbah banner dan suhu pembakaran) terhadap variabel terikat (kuat lekat beton) digunakan analisis regresi linier dan polinomial kuadratik.

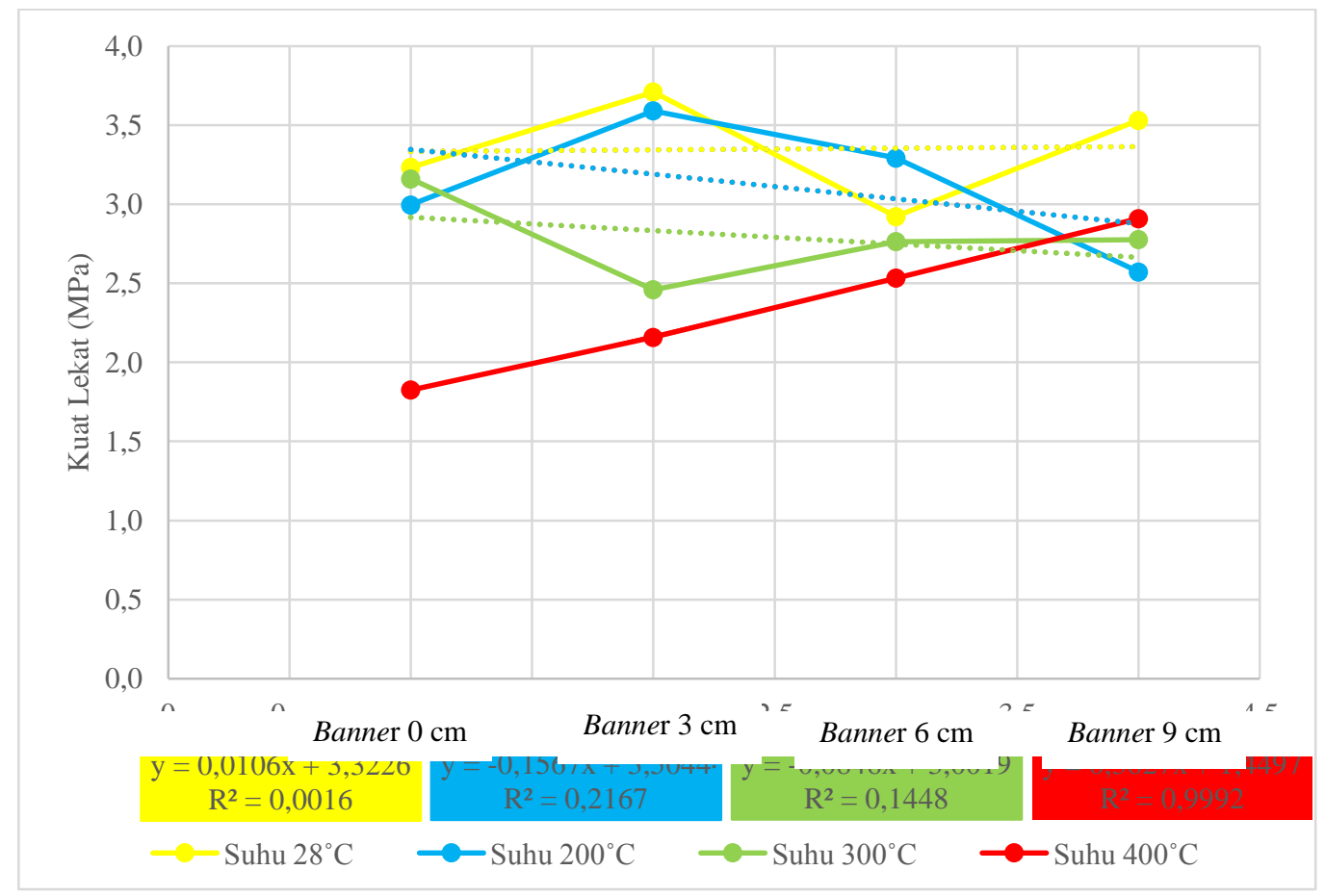

Gambar 2. Analisis Regresi Linier Hubungan Variasi Panjang Serat Limbah Banner Terhadap Kuat Lekat Beton Pada Suhu $28^{\circ} \mathrm{C}, 200^{\circ} \mathrm{C}, 300^{\circ} \mathrm{C}$, dan $400^{\circ} \mathrm{C}$ 


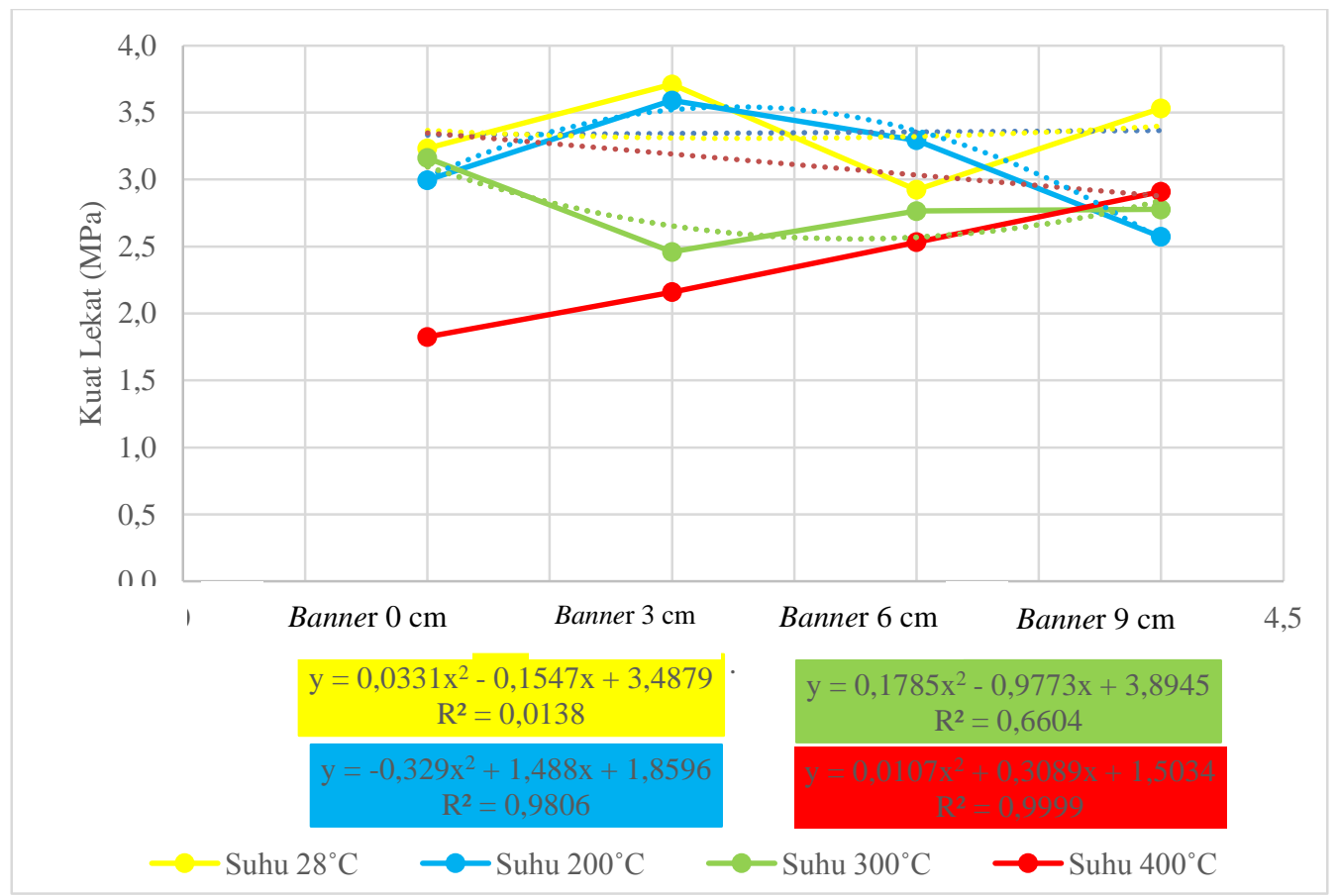

Gambar 3. Analisis Regresi Polinomial Hubungan Variasi Panjang Serat Limbah Banner Terhadap Kuat Lekat Beton Pada Suhu $28^{\circ} \mathrm{C}, 200^{\circ} \mathrm{C}, 300^{\circ} \mathrm{C}$, dan $400^{\circ} \mathrm{C}$

Dari grafik analisis regresi linier dapat dilihat bahwa regresi linier yang telah didapat banyak yang sangat menyimpang dari letak titik- titik dan nilai $R$ square juga sangat rendah. Karena itulah perlu memperbaikinya dengan regresi non-linier yaitu salah satunya dengan regresi polinomial kuadratik. Dapat dilihat dari grafik analisis regresi polinomial kuadratik bahwa hasil $R$ square pada analisis regresi polinomial kuadratik lebih besar daripada analisis regresi linier sehingga dipilih hasil dari analisis regresi polinomial kuadratik.

Dari hasil analisis regresi polinomial kuadratik dapat diketahui hasil regresi yang dihasilkan dari kuat lekat beton tanpa pembakaran yaitu dengan persamaan $\mathrm{y}=$ $0,0331 x^{2}-0,1547 x+3,4879$ dengan nilai $R^{2}=$ 0,0138. Dari nilai $\mathrm{R}^{2}$ dapat diketahui bahwa $1,38 \%$ variabel bebas mempengaruhi hasil dari variabel terikat, sedangkan 98,62 \% dipengaruhi oleh faktor - faktor lain. Dari hasil tersebut dapat disimpulkan bahwa variabel bebas memiliki pengaruh yang sangat rendah terhadap hasil variabel terikat.

Pada suhu pembakaran $200^{\circ} \mathrm{C}$ hasil regresi yang dihasilkan dari kuat lekat beton pasca bakar yaitu dengan persamaan $\mathrm{y}=$ $0,329 x^{2}+1,488 x+1,8596$ dengan nilai $R^{2}=$ 0,9806. Dari nilai $\mathbf{R}^{2}$ dapat diketahui bahwa 98,06\% variabel bebas mempengaruhi hasil dari variabel terikat, sedangkan 1,94\% dipengaruhi oleh faktor - faktor lain. Dari hasil tersebut dapat disimpulkan bahwa variabel bebas memiliki pengaruh yang sangat kuat terhadap hasil variabel terikat.

Pada suhu pembakaran $300^{\circ} \mathrm{C}$ hasil regresi yang dihasilkan dari kuat lekat beton pasca bakar yaitu dengan persamaan $\mathrm{y}=$ 
$0,1785 x^{2}-0,9773 x+3,8945$ dengan nilai $R^{2}=$ 0,6604. Dari nilai $\mathrm{R}^{2}$ dapat diketahui bahwa $66,04 \%$ variabel bebas mempengaruhi hasil dari variabel terikat, sedangkan 33,96\% dipengaruhi oleh faktor - faktor lain. Dari hasil tersebut dapat disimpulkan bahwa variabel bebas memiliki pengaruh yang kuat terhadap hasil variabel terikat.

Pada suhu pembakaran $400^{\circ} \mathrm{C}$ hasil regresi yang dihasilkan dari kuat lekat beton pasca bakar yaitu dengan persamaan $\mathrm{y}=$ $0,0107 \mathrm{x}^{2}+0,3089 \mathrm{x}+1,5034$ dengan nilai $\mathrm{R}^{2}=$ 0,9999. Dari nilai $\mathrm{R}^{2}$ dapat diketahui bahwa 99,99\% variabel bebas mempengaruhi hasil dari variabel terikat, sedangkan $0,01 \%$ dipengaruhi oleh faktor - faktor lain. Dari hasil tersebut dapat disimpulkan bahwa variabel bebas memiliki pengaruh yang sangat kuat terhadap hasil variabel terikat.

Pada suhu pembakaran $400^{\circ} \mathrm{C}$ kuat lekat beton mengalami kenaikan pada semua variasi penambahan serat limbah banner, hal ini terjadi karena kemungkinan pada suhu $400^{\circ} \mathrm{C}$ serat banner meleleh sehingga menambah rekatan antara beton dengan besi tulangan.

Dari hasil regresi polynomial kuadratik dapat disimpulkan bahwa penambahan serat limbah banner pada beton pra bakar hanya berpengaruh sangat rendah terhadap kuat lekat beton sedangkan penambahan serat limbah banner pada beton pasca bakar berpengaruh sangat kuat terhadap kuat lekat beton pasca bakar.
Nilai optimum penambahan serat limbah banner yang akan menghasilkan beton dengan kuat lekat maksimal beton pasca bakar

Berdasarkan gambar 1 dapat diketahui bahwa nilai optimum penambahan serat limbah banner yang menghasilkan bet on dengan kuat lekat maksimal yaitu pada penambahan serat limbah banner $3 \mathrm{~cm}$ dengan suhu pembakaran $200^{\circ} \mathrm{C}$ dengan nilai kuat lekat sebesar 3,590 MPa.

\section{KESIMPULAN}

1. Adanya penambahan serat limbah banner berpengaruh terhadap kuat lekat beton pasca bakar. Pengaruh yang dihasilkan terhadap penambahan serat limbah banner dengan hasil tertinggi pada penambahan serat limbah banner $9 \mathrm{~cm}$ pada suhu pembakaran $400^{\circ} \mathrm{C}$ dengan persentase $59,420 \%$ dengan kuat lekat 2,909 MPa.

2. Nilai optimum penambahan serat limbah banner yang akan menghasilkan beton dengan kuat lekat maksimal beton pasca bakar yaitu pada penambahan serat limbah banner $3 \mathrm{~cm}$ dengan suhu pembakaran $200^{\circ} \mathrm{C}$ dengan nilai kuat lekat sebesar 3,590 $\mathrm{MPa}$.

\section{Daftar Pustaka}

Apriliawati, Anisa. (2016). Kajian Kuat Lekat Dan Kuat Tekan Pada Beton Serat Dengan Bahan Tambah Potongan Limbah Banner. Skripsi. Surakarta : FKIP Universitas Sebelas Maret. 
Astanto, Triono Budi. (2001). Konstruksi Beton Bertulang. Yogyakarta : Kanisius.

Balaguru, P. \& Shah, S.P. (1992). Fibre Reinforced Cement Composites. Singapore : McGraw-Hill.

McCormac, Jack C. (2003). Desain Beton Bertulang. Bandung : Erlangga.

Nugraha, Paul dan Antoni. (2007). Teknologi Beton. Yogyakarta : Andi.

Setyowati, Edhi Wahyuni. (2016). Pengaruh Perubahan Microstruktur Beton Akibat Suhu Tinggi Terhadap Lebar Retak Balok Beton Bertulang. Rekayasa Sipil Volume 10 No.2 - 2016 ISSN 1978 -
5658. Malang : Jurusan Teknik Sipil Fakultas Teknik Universitas Brawijaya.

Sugiyono. (2016). Metode Penelitian Kuantitatif, Kualitataif, dan $R \& D$. Bandung : Alfabeta.

Wahyuni, E. \& Anggraini, R. (2010). Pengaruh Perbedaan Proses Pendinginan Terhadap Perubahan Fisik Dan Kuat Tekan Beton Pasca Bakar. Jurnal Rekayasa Sipil Volume 4 No.1- 2010 ISSN 1978 - 5658.

Wang, Chu-Kia dan Salmon, Charles G. (1992). Disain Beton Bertulang. Bandung : Erlangga. 